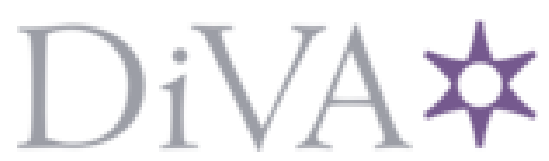

http://www.diva-portal.org

\title{
Postprint
}

This is the accepted version of a paper published in Journal of Men's Studies. This paper has been peerreviewed but does not include the final publisher proof-corrections or journal pagination.

Citation for the original published paper (version of record):

Zackariasson, M. (2009)

Angry young men?: masculinities and emotion among young male activists in the Global Justice Movement.

Journal of Men's Studies, 17(1): 31-46

Access to the published version may require subscription.

N.B. When citing this work, cite the original published paper.

Permanent link to this version:

http://urn.kb.se/resolve?urn=urn:nbn:se:sh:diva-5530 


\section{Angry Young Men? \\ Masculinities and Emotion among Young Male Activists \\ in the Global Justice Movement}

Maria Zackariasson

This article is based on qualitative interviews with a number of young men who are active in the global justice movement in Scandinavia, and particularly examines what role anger may have in their political involvement. The individual narratives and reflections from the interviews are discussed in relation to the role of emotions in how and why individuals get involved in social movements, and to various meanings and popular understandings of the emotion anger. The interview material is also related to cultural conceptions of masculinity and youth, with particular reference to the dominating media image of young activists in the global justice movement in Scandinavia, which to a large extent has focused on aggressive behaviour and violence.

Keywords: young men, emotions, anger, global justice movement, political involvement 
Researchers in various disciplines within the humanities and social sciences have in different ways acknowledged the cultural and social aspects of emotions. The biological and psychological reactions occurring within the human body and mind, have been related to features such as gender, class, and ethnicity. It is thus not necessarily the feelings themselves that form the centre of attention, but rather how our experience of these feelings, whether they occur in us or in others, are shaped by the cultural and social context. The way we express our feelings is also seen as influenced by the social and cultural context around us, and the same can be said of how we regard, and react to the emotional expressions of people in our surroundings (Ahmed, 2004, Hochschild, 2003). According to this way of regarding emotions, factors such as age, gender, and social position are highly significant both for what emotions the individual expresses and how this is done. Who you are, and who others assume you to be, is however also influential for how others interpret and understand your emotional expressions (cf: Fischer, 1991).

One area where the role of emotions has received increasing attention, is the research on social movements. Studies of why and how people become active in social movements have, for instance, shown that different emotions may be crucial for what particular movement or cause individuals become active in, as well as for if they stay active (Della Porta \& Diani, 2006, Goodwin \& Jasper, 2004, Goodwin, Jasper \& Polletta 2001). ${ }^{1}$ The importance of emotions in social movements may be seen as connected to the tendency within many of them to view political convictions as something that characterizes you as a person as well as your everyday life and actions, rather than as something you can easily step in and out of. You are thus not only expected to be intellectually engaged, but also practically, socially and emotionally, even though this ideal is far from always fulfilled in practice. ${ }^{2}$

In this article, I will look at the significance of anger in young men's involvement in the global justice movement in Scandinavia, and relate this to cultural conceptions of masculinity and youth. The analysis is based on material from a qualitative research project on political involvement among young people in Sweden and Norway. In this project, I followed the activities of three different local groups that all belonged to the global justice movement. In addition to doing participant observation in the three groups, I conducted qualitative interviews with 18 of the youngest members, both men and women, who were between 19 and 27 years old at the time of the study. Here I will concentrate on the young men.

The global justice movement is a rather recent social movement. It consists of a number of organizations, activist groups and networks, which are characterized by a critical attitude toward neo-liberal market economy, a will to improve the uneven distribution of goods 
between the rich and the poor countries in the world, and a wish to work for spread and deepened democracy (Della Porta \& Diani, 2006). The demonstrations around the summit meeting in Seattle in 1999 is often seen as one of the starting points of the movement, and two of its influential components are the World Social Forum and, from a European perspective, the organization Attac. ${ }^{3}$ The groups that I followed consisted of two local branches of Attac, one in Sweden and one in Norway, and one group that worked with organizing a local Social Forum.

To look at the role of anger in young men's involvement in the global justice movement is interesting for several reasons. First of all because the participants in the study emphasized that being upset with or angry at the state of the world was one major motive for why they had become politically active. Secondly, because anger and aggression were central elements in many of the media reports from the large demonstrations arranged by the global justice movement from 1999 and onwards in Scandinavia and other European countries (Della Porta \& Diani, 2006; see also Göteborgskommittén, 2002; Lundälv \& Liliequist, 2002). It was particularly the young men who the mainstream media portrayed as angry, aggressive and potentially violent, which is the main reason why I in this article concentrate on the male participants in the study, only occasionally referring to the female activists. I will return to the connections between masculinity, violence, and youth later on in the article.

\section{Being Upset with Injustices}

The emotions that contribute to a person's decision to become active in a social movement may be of several kinds (Goodwin \& Jasper, 2004; Goodwin, Jasper \& Polletta, 2001). Groves (2001), for instance, notes that compassion is a contributing factor for women who are active in the animal rights movement in the U.S. Pride might be another significant emotion, compelling individuals to fight for their rights, as in the civil rights movement of the 1960s or the gay- and lesbian movement of the 1980s (Breines, 1982; Gould, 2001). Fear may also contribute to mobilizing people, which has been evident in the environmental movement, for example, in the debates around the risks of global warming.

As I mentioned above, the most common emotionally related explanation for why the young men in my study were politically active, was that they were upset or angry with the way society works, and especially upset with what they saw as obvious injustices in the world. Emil, who was twenty-three years old when I interviewed him, explained it like this: 
Emil: I'm engaged in the injustices of the world, so to speak. So that ... yeah, it sort of boils down to that. "This is unjust." It goes against my feeling of fairness.

Interviewer: Is that what motivates you as well?

Emil: Yes it is, isn't it. That's the thing. Moral indignation (laughs), right? That's what it boils down to. Even if ... you know ... what is justice and so on. But I'm quite clear on what I find unfair. And that's what motivates me.... I'm trying to think of ... why [did I involve myself] internationally? Why not the women's movement instead, you know.... But there is no doubt that the huge differences between the rich and the poor is the greatest injustice we have in the world, so it's difficult to get around that. (Emil, $2004.01 .12)^{4}$

That Emil has a strong sense of fairness and a will to fight against injustice is, according to himself, an essential part of why he has become politically active. It also has consequences for what causes he is engaged in. Since he sees the uneven distribution of goods between the rich and the poor in the world as the greatest injustice, this is what upsets him the most and he thus finds it to be the most pressing issue to work with.

Hannes, another of the participants in the study, who was nineteen at the time of the interview, was also upset with injustices in the world, but unlike Emil, he saw the relations between men and women as the most fundamental issue:

Hannes: Feminism was maybe the first thing that I was in contact with politically, and could take a stand for and knew what I meant and so on.

Interviewer: How did you get into that?

Hannes: I think it was sort of ... it's so completely present somehow. So I think it was more a question of that I started to realize to what extent women and girls around me were treated so damn badly! I guess I belong to those who think it's worse than it's described in the media and in what's written about it. I think people could be more outspoken about it. I don't think women either understand how bad it is.

Interviewer: No?

Hannes: Because they have never been men you know. They don't know how well you are treated if you are a man. I think that's a good thing. That men can contribute that to feminism; that they know what it's like to be a man. They know how well off you can be. (Hannes, 2003.05.20) 
In Agneta Fischer's (1991) analysis of the popular understanding of anger among Dutch people, she shows that it is an emotion, which can be viewed both as something positive and as something negative (see pp. 138, 165-ff). If it is to be seen as positive or not, is directly related to the social and cultural context where it is expressed. When others share the view that the individual has a cause for anger, i.e., when they agree that the situation or action that stirred the anger was in fact wrong, unfair or intolerable, they are likely to see it as justified, and thus accept and support the emotional reaction. In the opposite case, when the community does not share the individual's assessment, the anger is more likely to be regarded as problematic. How the anger is expressed, is also significant, in the sense that the individual's way of showing anger should not challenge the dominant views on when, where and in what way it is appropriate to do so, if it is to be considered a good thing. Other influential aspects include the social standing of the individuals showing the anger and the relation they have to the person who has affronted them, but these are aspects I shall not develop further here.

That anger in many cases is regarded as a positive thing, is partly based on the idea that it leads to action. If fear is often comprehended as a paralyzing emotion, anger is seen as potentially constructive, based in the conception that if you get angry, you act, which enables you to change your situation (Barbalet, 1998; Fischer, 1991). Another quotation from the interview with Hannes exemplifies how this aspect of anger was reflected in my material:

Hannes: We started a society as well. Or rather some people started a group that I joined, which was called SAME. It was a ... we called it an egalitarian feminist group....

Interviewer: So, what did you do?

Hannes: To start with we arranged a ... what I'm slightly sceptical to but still think is OK ... because we were so young. We had a demonstration against sexual violence. Maybe that should have been formulated in another way, like a manifestation instead. Who are you saying it to, you know? All men? That's the big thing we did and we lived on that for a very long time. 'Cause it gathered around three, four, five hundred people maybe.

Interviewer: Mhm, great.

Hannes: We mobilised amazingly fast. We were like: We have to do something about this shit! Go out and show them what we think! And I think we were rather angry as well. (Hannes, 2003.05.20)

The event that Hannes refers to in the excerpt, which inspired them to organise a demonstration, was a much discussed rape-case in Stockholm, where a young girl got raped by a group of boys. The current media debate circled around whether the perpetrators got 
away too easily, among other things because the girl was too intoxicated to put up much resistance.

In his reflections in the interview, which took place a couple of years after the actual event, Hannes alternates between seeming quite proud of what they had achieved and being slightly critical of how they handled the situation. The excerpt above shows how he uses the fact that he and his friends were quite young at the time, as an explanation and partly as a defence for why they decided to act the way they did. I want to argue that he in doing so can be seen as tying on to a well established cultural conception of youth as immature and impulsive, and that such an implicit understanding of what it means to be young becomes the basis for his explanation of why they maybe did not find the ultimate way of expressing their opinions (cf: France, 2007; Wyn \& White, 1997).

He does, however, not make any excuses for the anger they felt. That he and his friends were angry is rather presented as something positive. One reason for this is explicitly expressed in the quotation: that it contributed to them taking action and organizing the whole thing on such short notice. His description of the situation thus fits in with my discussion above of how the association between anger and taking action is one aspect that contributes to it being regarded as a positive emotion (cf: Barbalet, 1998; Fischer, 1991).

I also want to point to another possible reason for why Hannes primarily presents their anger in positive terms, namely that it is not expressed on behalf of themselves but on behalf of others. This aspect is quite visible in the interview with Emil as well. Neither he nor Hannes are directly negatively affected by the injustices they are upset about - the differences in life situations between the rich and the poor or men and women - since they belong to what they see as the more favoured part of each dichotomy through being Scandinavians and men. They fight for someone else: suppressed women, the poor in the world — and when you defend not your own honour but the honour of those who are less able to do it themselves, the chances increase for the anger to appear as a good thing rather than as something threatening or negative (cf: Gross, 2006, pp. 3-ff).

\section{Changing the World-Revolution or Evolution?}

The Norwegian researcher Knut Kolnar (2006) has written about the connection between masculinity and violence, and how the use of violence may have opposite effects, depending on whether it is considered acceptable and justifiable in the cultural and social context where it takes place. He argues that violence has the potential both to strengthen the individual's 
position in a specific context and to weaken it, making him marginalised or stigmatized. In many respects the expression of anger works in the same way. It may strengthen the individual's position, if it is seen as a way of standing up for oneself or for others, but it may also weaken it, if it is considered unfounded or out of place. This is especially true if the anger is expressed in a way that is considered inappropriate, as I mentioned above, or if it cannot be controlled by the individual (Fischer, 1991).

Such negative images of anger, where it is seen as expressed in an unacceptable manner, recurred in the media reports about the major demonstrations arranged by the global justice movement in many European cities at the beginning of the $21^{\text {st }}$ century (Della Porta \& Diani, 2006). Generally these demonstrations were intended to be peaceful, and many of them were. But it was the ones that turned into violent protests, with riots and clashes between protesters and the police, which got the biggest headlines and the most media coverage. Genova in Italy in 2001 and Rostock in Germany in 2007 are two examples, but from a Scandinavian point of view, the most significant event took place in Gothenburg, Sweden, in June 2001.

At this time various groups and NGO's joined forces in order to arrange demonstrations against the EU-summit meeting that was taking place. Even though the ambition was to keep the manifestations peaceful, there occurred several instances of violence, vandalism and fights with the police, to the disbelief of the everyday Swedes who read about the events in the newspapers (Göteborgskommittén, 2002; Lundälv \& Liliequist, 2002). The police was afterwards criticized for their sometimes violent behaviour toward the protesters, but the initial media reports focused mainly on aggression among the demonstrators, and, as I said initially, it was to a large extent the young men who were linked to the violence in these reports.

The media images of "angry young men," affected not just the general public, but also the young activists themselves, which is shown in how the male participants in my study reflected upon their own involvement in the global justice movement. Most of them tried to distance themselves from the images of angry young activists in violent revolts against society, by clearly stating a non-violence position. Nils was one of those who talked about how he did not consider revolution to be a good idea. He underlined that he had no wish to overthrow the existing society, and definitely not through using violence. What he aimed for was slow changes, an evolution rather than a revolution. He argued that only through taking small steps, would it be possible to achieve real and lasting changes (Nils, 2003.03.06). 
Victor, who was twenty-seven at the time of the interview, also supported a non-violence approach, but had a slightly more tolerant attitude toward the use of violence in certain situations and toward those who are unable to keep their emotions under control:

Victor: I think you should have a non-violence strategy in relation to demonstrations. At the same time I can understand that people, that it boils over for people, if they are attacked by the police without having provoked them. But I still think you should counter it with a non-violence strategy. It's the only thing that works.

Interviewer: Is that because it's the most efficient thing to do, or because it's ethically wrong (to use violence)?

Victor: It's both, of course. But the ethical side is important here. It is wrong to use violence. You have to remember, at demonstrations, that the policemen are individuals too. They are there to do a job. You can't be sure that they actually disagree with the political views (you represent). But it's not that you shouldn't hit the police because you might have sympathizers there. It's a question of principle. I think it is right to try to deconstruct conflicts between groups generally. But with that said - I can still understand that you use violence as part of a struggle for liberation in countries where you don't have the right of free speech, free press and such things. Then I can understand it. But at the same time the use of violence tends to lead to more violence, and that wouldn't be good either. It's a difficult question really. (Victor, 2003.10.14)

In his reflections, Victor automatically associates violence with anger, when he describes violent behaviour in demonstrations primarily as a result of "boiling over," i.e. of becoming so angry, for example, by being provoked by the police, that you cannot control your feelings any longer. Even though he is against violence generally, he can thus understand that emotions, and in this case anger, get so strong that they become almost impossible to control. This view is quite consistent with Sally Robinson's (2002) description of how the construction of masculinity in the U.S. has been tied to an image of violent emotions, anger in particular, that are on the verge of explosion, as a consequence of men's apparent inability to verbalise them.

The connection between anger, violence and masculinity is a significant element in the dominant cultural conceptions of masculinity also in the Scandinavian countries (Kolnar 2006; also cf: Ekenstam, Johansson, \& Kuosmanen, 2001; Ekenstam \& Lorentzen, 2006). It becomes particularly visible in the conceptions of young men. Youth is a period in life that has traditionally been associated with emotional turmoil and impulsiveness, and especially 
male youth cultures have to a large extent been associated with anger; anger at the parental generation or at the established society (Bjurström 1997; France, 2007). This recurring connection between young men and aggressive behaviour, might partly explain why it is particularly the young men who are portrayed as violent trouble makers in the media accounts of the global justice movement and mass demonstrations, even in those cases when young women are also active in the protests and in the clashes with the police (Zackariasson, 2006).

\section{Controlled Anger}

Victor expressed a certain understanding for those individuals who could not handle their emotions in a pressed situation. But others that I interviewed stressed the importance of controlling your anger, even though you might experience provocations. Linus, who was one of those who had actually participated in protests that involved violence or confrontations with the police, emphasized the need of staying calm, no matter what happened:

Linus: There was a pro-Isreali demonstration yesterday. And the Syndicalist Youth group helped organizing a counter-demonstration that got a bit messy. I have loads of marks here (shows his arms). The police went in with ... I got hit in the face with a horse-whip, and police batons.... It was full chaos.

Interviewer: How many people participated in the counter-demonstration?

Linus: Around three, four hundred.... I got information about it just the day before. So they got it together really quickly. I don't know ... I got really surprised actually. That the police was so forceful. 'Cause we were going to have a meeting. We weren't going to try to stop their demonstration. We just stood there trying to make our voices heard. But we were driven all the way up ... along the street, several hundred meters, with horses and everything.... But even though we were attacked, we managed to keep it non-violent. There were no counterattacks from the demonstrators. And I think that's quite important. That you manage to keep the calm within the demonstration, even though you're attacked. (Linus, 2002.05.06)

One of the things Agneta Fischer (1991) noted in her study of conceptions of anger among Dutch people, was that there existed a popular understanding of that it is good to express your anger, both for the individual personally, and in relation to others (also cf: Robinson, 2002). The general idea, which has become widespread also in the Scandinavian countries, is that if you do not let your anger out, but keep it bottled up, it slowly poisons you from the inside. 
But, as I discussed above, if anger is seen as good or not, also depends on how, when, where and for what reasons it is expressed. And uncontrolled anger, i.e., when the anger causes people to act in ways they would not have acted, had they been in control of the situation and their emotions, tends to be viewed as problematic (Fischer, 1991; also cf: Robinson, 2002).

When the individual(s) cannot control their anger, it becomes potentially dangerous, not necessarily in a physical sense, but in the sense that it becomes more forceful than it would otherwise have been. There is a risk that things are said that should not have been said, or that things are done that should not have been done, regardless of where the anger occurs: in a lovers' quarrel, in a hectic traffic situation, in a heated discussion, etc. Uncontrolled anger and the actions it leads to, also run the risk of affecting or harming people who are not the primary target, but happen to be in the wrong place at the wrong time.

When Linus, in the quotation above, talks positively and proudly about how they managed to keep the demonstration calm and under control, it may be understood in relation to these negative aspects of uncontrolled anger. There was a real risk that the planned peaceful protest march would turn into a riot or violent fights with the police. But if the demonstrators had behaved aggressively or violently, it might have harmed their cause through taking away the focus from the issue they were really fighting for: how the Israelis were treating the Palestinians.

The anger or indignation they felt about this, was in many ways the very foundation for the demonstration. This is the same kind of anger that was evident in the interviews with Emil and Hannes above, anger on behalf of others who you think are treated unfairly. It might thus qualify for being considered justified and righteous, even if not everyone would agree with the specific case made. If the demonstrators turned their anger at the police, they however would risk that this first anger was overshadowed by the second. The focus of attention could, and probably would, shift from the indignation over the relations between Israel and Palestine to the aggression of the protesters.

Such behaviour would furthermore add to the existing media image of young activists as violent and out of control, and as dangerous for the surrounding society. Instead of being regarded as genuinely engaged in specific political issues, they would run the risk of appearing as fighting merely for the sake of fighting. There were in other words several reasons for why controlling your anger - only directing it at the intended target, not taking out your frustrations through fights with the police etc.- - would appear beneficial in this situation, and thus for why Linus emphasized the importance of this in the interview. 
Linus also underlines that they had no intention of actually disturbing the other demonstration, and therefore he did not expect to be treated the way they were by the police. But sometimes clashes with the police are a calculated part of the demonstration. This was evident in Hannes' description of his experiences from a large scale demonstration in Copenhagen:

Hannes: I went (to Copenhagen) with an organization called XX. Because I know a guy there, so I could stay with them.... We joined the "liberal section."... That was for the liberal (socialists), and then the anarchists walked in their own section. So it was some kind of "Black block" thing. And it was very clear: "Those of you who want to walk in the chains (front lines), you walk at the front. Come over here to the car and we'll get in place. Those of you who want to walk behind, you walk behind," sort of. And the thing is, that you wear black clothes, it's not just because you want to be cool. It's also a way to avoid being registered. A lot of people say it's only a matter of lifestyle. But it's really necessary for many of them. And they are in the chains (front lines). And they.... It's like ... I felt that we backed each other the whole time. It was like ... if something would happen, they (the police) would get those in the front lines. A fight. But then they expect us to back them up, and keep up behind them. So that the police can't just go in and get them.

(Hannes, 2003.05.20)

In Hannes' account above, it is not anger that is the most visible emotion, but rather admiration and loyalty. Even though he would not walk in the front lines himself, he appears to respect and admire those who do. It is also evident that he in a way felt obligated to be loyal to those in the front lines, for example through keeping the procession together and not leaving any gaps where the police could step in and cut off the assumed trouble makers.

\section{Anger, Fear and Ideas of Masculinity}

Linus, in the quotation earlier, expressed surprise at the attitude of the police officers, and pride that they managed to keep the demonstration non-violent. Joel, another of the young men I interviewed, had participated in the partly violent demonstrations in Gothenburg 2001. When he talked about his experiences, he underlined the strangeness of the situation, how odd he found it to suddenly hear rumours of people being hurt, witness protesters throwing stones 
and the police treating them with hostility (Joel, 2002.10.06). What neither of them mentioned was if they felt any fear in the given situation.

Fear is an emotion that is common in the media accounts of violent protests, but it is usually attributed to the "innocent victims": the shop owners, the bystanders, old ladies who happen to get caught in the middle, etc. ${ }^{5}$ The male activists are very rarely portrayed as feeling any fear. In Hannes' story about his experiences in Copenhagen, it did however become clear that this may be a significant emotion also for the protesters:

Hannes: One quite scary thing, that we still laughed a bit about, was that we ... we had some kind of meeting before (the demonstration). What we were going to do and so on.... And then ... we got phone numbers to lawyers who were OK, you know. Who should we call if we got arrested, sort of. They distributed those. And then it was like: Here's the number to ANTIFA (Anti-fascist action)." 'Cause they had written on anarchist ... or on nazi-webpages, that they were going to beat up left wing activists during the meeting. And they wanted us to know that. So we got this number to ANTIFA that you could call if you were ... if the neo-nazis came. And we sort of laughed a bit and: "Yeah, OK, shit, and what will they do?", you know. And they just: "Well, just call if it becomes necessary." And that was just the thing you know: Who do you call if it is the cops you are afraid of? For us it was ANTIFA. We didn't know what they would come up with, but what if some neo-nazis had shown up, and were going to start beating me? Then who would I call? I couldn't call the police and say like: "The Nazis are here now." I don't think they would come.

Interviewer: No...

Hannes: Unfortunately not. They are too keen on hunting me, so they don't have the time to protect me. (Hannes, 2003.05.20)

It is not remarkable that most of the young men in my study did not spontaneously talk about fear in connection with protests they had taken part in. Fear is an emotion that mainly has negative connotations, and to admit being afraid is consequently not necessarily something desirable for the individual (Dozier, 1998; Fischer, 1991). It is, furthermore, an emotion that is not generally a part of the cultural conceptions of young men, in fact, it may in many contexts be regarded as "unmanly" (cf: Ekenstam, Johansson \& Kuosmanen, 2001; Ekenstam \& Lorentzen, 2006; Seidler, 2006). Young men as angry and eager to change the world, is part of a familiar image that was quite natural for the individuals in my study to relate to and 
associate themselves with. To be afraid while trying to do so is not to the same extent part of the general image and this makes fear a less likely emotion to mention in the interviews.

That Hannes still chooses to talk to me about the fear he felt, may be understood in light of the conversational context of the interview. When talking to his activist mates he might want to portray himself as fearless and aggressive, like the people who chose to walk in the front lines of the demonstration appeared to be. When talking to his middle-class parents he might downplay both the risk of being arrested and the risk of being attacked by right-wing activists, and hence also the fear he felt. But in this particular situation he is talking to me, a researcher who did not participate in the demonstration and who does not know the friends he went there with. He also knows that the interview will be anonymized. Victor Seidler (2006) comments that it can be difficult to interview men about sensitive topics and emotions, since talking about such things in an interview situation might make them feel vulnerable. But it is also possible to see the interview situation as a free space, where the individual finds it easier to express things he (or she) would otherwise hesitate to discuss openly. The interview situation might hence be seen as giving Hannes the freedom to talk about emotions that he would possibly not feel comfortable expressing in other contexts. ${ }^{6}$

Another way of understanding Hannes' openness about his emotions, both anger and fear, is, however, that the verbal expression of emotions was something quite natural to him. In one part of the interview he explained that he tried to be "as little of a man as possible," an ambition based on his feminist values. Even though he did not see this as something that all men must or should do, he still regarded it as one significant way of trying to influence the gender relations in society. This is an attitude mirrored in a study by the Swedish sociologist Cathrin Wasshede (2005), on young men who define themselves as feminists. In a manner similar to Hannes, the young men in her study emphasized the responsibility men have in upholding or changing the existing gender structures, and they tended to distance themselves from the category of "men in general" (pp. 86-ff).

The fact that they themselves were men did, in other words, not mean that they sympathized with how men in general act or with the current gender system in society. Instead they, like Hannes, wanted to represent a different kind of masculinity, a different way of being a man, than the one prevalent in society at large. Talking about your emotions, and especially admitting your fear, could easily be seen as a way of challenging hegemonic masculinity and the traditional ways of being a man, considering the still dominating view of men as reluctant or unable to talk about their feelings (Ekenstam et al., 2001; Ekenstam \& Lorentzen, 2006; McInnes, 2001; Robinson, 2002; Seidler, 2006; Wasshede, 2005). 


\section{Complexity and Contradictions - Concluding Discussion}

In this article I have suggested that anger in several ways is a significant emotion in the political involvement of young men in the global justice movement. The interviews I have made exemplify how anger can be a vital part in why individuals decide to become politically active in the first place, as well as for how their engagement is put into practice. Worth noting is, however, that this aspect was visible also in the interviews I made with young women. In a manner similar to the young men, they talked about how they became angry for instance at things they had read in the newspaper and that this encouraged them to take action (Zackariasson, 2006). When it came to this kind of anger, there were in other words no great differences between the young men and the young women in the study.

When the participants in the study talked about their anger in this context, they in various ways indicated that it was a question of righteous anger, and that they were not angry on behalf of themselves, but on behalf of others who were less able to fight for their rights. That their anger was a factor in their decision to become active in the global justice movement, further contributed to defining it as something good, since the relation between anger and action is part of why this emotion in some situations is regarded as something commendable and positive.

But, as I have discussed above, anger can also be considered negative, especially when it is associated with aggressiveness and the use of violence, or when it is perceived as being out of control. This kind of anger may be seen as connected to both the conception of masculinity, based on the idea that men are on the verge of explosion as a result of their inability to express their emotions, and the conception of young people as less mature and therefore less able to control their emotions than adults. It was such negative representations of anger that dominated many of the media reports about young male activists in the Scandinavian countries in the beginning of the $21^{\text {st }}$ century. This had special impact on the male participants in my study, seeing that they were both young, men and activists, but did not want to be associated with such images. It was therefore necessary for them to clearly distance themselves from these representations and hence from that kind of anger.

They did this mainly by opposing the use of violence as a means of achieving political goals, and by emphasizing the need to keep their emotions under control even when being provoked by others. Keeping your emotions under control is another element in the modern, Western construction of masculinity. But since this has come to be seen as potentially 
problematic, from the perspective that it is viewed as good to let your feelings out, young men nowadays must try to find a balance between controlling their anger and expressing it. I want to argue that the young men in this study thus may be seen as navigating between the different and sometimes contradictory expectations directed at young men in Scandinavia today; you should express your emotions, also your anger, but it is not acceptable to do this in an aggressive or violent manner.

To conclude with, I particularly want to emphasize the complexity of the individual views and reflections within the interviews. My analysis illustrates that a person's emotional expressions and views on masculinity are far from simple and straightforward, but rather consist of many different parts and pieces, which may make them appear as contradictory and inconsistent, but still make up a whole. ${ }^{7}$ The interviews show, for instance, that it is possible for a person to base his political involvement on anger at things he finds wrong, and at the same time clearly oppose the uncontrolled use of anger or violent behaviour, like Linus did. It is also possible to express an understanding for those who lose their tempers in encounters with the police, and simultaneously defend a distinctly non-violence position, like Victor. It is even possible, like Hannes, to have the ambition of being "as little of a man as possible" and still walk among and support the confrontation seeking young activists in the demonstrations, who, in many respects, represent a very different masculinity.

The complexity of the reflections, both concerning the expression of emotions and what kind of masculinity ideals they relate to, is of course connected to the fact that each person is part of many different significant contexts, which might include and encourage different ideals and expectations. Just as gender and age are significant factors for how individuals express their emotions, so are the context and the company they find themselves in. Qualitative research interviews give the young individuals a chance to expand upon their various opinions, values and attitudes, and thus allow a more complex analysis of both emotions and masculinity. This makes interview material of this kind an important and necessary supplement to the quite one-dimensional media image of "angry young men" in the global justice movement.

\section{References}

Ahmed, S. (2004). The cultural politics of emotion. Edinburgh: Edinburgh University Press. 
Barbalet, J. M. (1998). Emotion, social theory, and social structure: A macro sociological approach. Cambridge University Press: Cambridge.

Berntsen, M. S. (2002). ATTAC Norway: An anthropological study of the Norwegian branch of a transnational social movement. University of Oslo:Oslo.

Bjurström, E. (1997). Högt \& lågt: Smak och stil $i$ ungdomskulturen. (High and low: Taste and style in youth culture). Umeå: Boréa.

Breines, W. (1982). Community and organization in the New Left 1962-1968: The great refusal. New York: Praeger.

Della Porta, D., \& Diani, M. (2006). Social movements: An introduction. Oxford: Blackwell.

Dozier, R. W. (1998). Fear itself: The origin and nature of the powerful emotion that shapes our lives and our world. New York: St Martins Press.

Ekenstam, C., Johansson, T., \& Kuosmanen, J. (2001). Sprickor i fasaden. Manligheter $i$ förändring. En antologi. (Cracks in the facade. Masculinities in change. An anthology). Hedemora: Gidlunds.

Ekenstam, C., \& Lorentzen, J. (2006). Män i Norden: Manlighet och modernitet 1840-1940. (Men in the Nordic countries. Masculinity and modernity 1840-1940). Hedemora:Gidlunds.

Eschle, C., \& Maiguashca, B. (2005). Critical theories, international relations and "the antiglobalisation movement": The politics of global resistance. New York: Routledge.

Fischer, A. H. (1991). Emotion scripts: A study of the social and cognitive facets of emotions. Leiden: DSWO Press.

France, A. (2007). Understanding youth in late modernity. Maidenhead: Open University Press.

Giddens, A. (1994). Beyond left and right: The future of radical politics. Cambridge: Polity Press.

Goodwin, J., \& Jasper, J. M. (2004). Rethinking social movements: Structure, meaning, and emotion. Lanham, Md.: Rowman \& Littlefield.

Goodwin, J., Jasper, J.M., \& Polletta, F. (2001). Passionate politics: Emotions and social movements. Chicago: University of Chicago Press.

Göteborgskommittén. (2002). Göteborg 2001: Betänkande. (Gothenburg 2001: Report). Stockholm: Fritzes offentliga publikationer.

Gould, D. B. (2001). Rock the boat, don't rock the boat, baby: Ambivalence and the emergence of militant AIDS activism. In J. Goodwin, J.M. Jasper \& F. Polletta (Eds.), 
Passionate politics: Emotions and social movements (pp. 155-175). Chicago \& London: University of Chicago Press.

Gross, D. M. (2006). The secret history of emotion: From Aristotle's "Rhetoric" to modern brain science. Chicago: University of Chicago Press.

Groves, J. M. (2001). Animal rights and the politics of emotion: Folk constructs of emotions in the animal rights movement. In J. Goodwin J.M. Jasper \& F. Polletta (Eds.), Passionate politics: Emotions and social movements (pp. 212-229). Chicago: The University of Chicago Press.

Hochschild, A. R. (2003). The managed heart: Commercialization of human feeling. Berkeley: University of California Press.

Kolnar, K. (2006). Volden (Violence). In J. Lorentzen \& C. Ekenstam (Eds.), Män i Norden. Manlighet och modernitet 1840-1940. (Men in the Nordic countries. Masculinity and modernity 1840-1940). (pp. 208-228) Hedemora: Gidlunds.

Lundälv, J. \& Liliequist, M. (2002). Gatans politik: Göteborgsdemonstrationerna juni 2001 ur mediernas, polisernas och demonstranternas perspektiv. (Street politics: The Gothenburg demonstrations in June 2001, from the perspective of the media, the police and the demonstrators). Gävle: Meyer Information och förlag.

MacInnes, J. (2001). The crisis of masculinity and the politics of identity. In S. M. Whitehead \& F. J. Barrett (Eds.), The masculinities reader (pp. 311-329). Cambridge: Polity press.

Olsen, T. (2002, June 13). Frykter pøbeldemonstranter under Verdensbank-møtet. Skal beskytte butikken med balltre. (He fears mob demonstrators during the World Bank meeting. Will protect his shop with a bat). Aftenposten. Retrieved 23, August 2004 from atekst.mediearkivet.no.

Patomäki, H., \& Teivainen, T. (2004). A possible world: Democratic transformation of global institutions. London: Zed Books.

Polet, F., \& Houtart, F. (2001). The other Davos: The globalization of resistance to the world economic system. London: Zed Books.

Ponniah, T., \& Fisher, W. F. (2003). Another world is possible: Popular alternatives to globalization at the World Social Forum. London: Zed Books.

Robinson, S. (2002). Men's liberation, men's wounds. Emotion, sexuality and the reconstruction of masculinity in the 1970s. In M. Shamir \& J. Travis (Eds.), Boys don't cry? Rethinking narratives of masculinity and emotion in the U.S. (pp. 205-229). New York: Columbia University Press. 
Sandberg, S. (2003). The success of ATTAC in Norway: An approach synthesising discourse analysis and framing theory. University of Oslo: Oslo.

Seidler, V. J. (2006). Young men and masculinities: Global cultures and intimate lives. London: Zed Books.

Wyn, J., \& White, R. (1997). Rethinking youth. London: Sage.

Wasshede, C. (2005). Skägg och kjol? Unga aktivistmän om maskulinitet och femininitet. (Beard and skirt? Young male activists on masculinity and femininity). In T. Johansson (Ed.), Manlighetens omvandlingar: Ungdom, sexualitet och kön i heteronormativitetens gränstrakter. (Transformations of masculinity: Youth, sexuality and gender in the borderlands of heteronormativity). (pp. 81-114). Göteborg: Daidalos.

Zackariasson, M. (2006). Viljan att förändra världen. Politiskt engagemang hos unga i den globala rättviserörelsen. (The will to change the world. Political involvement among young people in the Global Justice movement). Umeå: Boréa.

\footnotetext{
${ }^{1}$ There is a large amount of research on social movements, and in this article I mainly refer to studies that use an emotional theoretical approach.

2 This is related to Anthony Giddens' concept, life politics, which is sometimes used to understand how political values and everyday life may be interconnected. Giddens mainly sees this as part of the development of the political processes in the late modern society (Giddens, 1994). He has however been criticized for putting too much emphasis on the individual level and life style, and not enough on other aspects.

${ }^{3}$ Attac was founded in France in 1998 and has national and local branches in many countries in Europe and Latin America, as well as in other parts of the world. At the turn of the century, this organization gained media attention and the public debate in several European countries, and attracted numerous members, many of which were young (Berntsen, 2002; Eschle \& Maiguashca, 2005; Sandberg, 2003). The World Social Forum was established in 2001 in Porto Alegre, Brazil. It aims to be a meeting place for activists and NGO's from all over the world. The $W S F$ was originally meant to be an alternative to the annual economic top meeting in Davos, Switzerland ( Patomäki \& Teivainen, 2004; Polet \& Houtart, 2001; Ponniah \& Fisher, 2003).

4 The interview excerpts are translated from Swedish and Norwegian by the author. The brackets below the extract contain the fictitious name of the participant and the date the interview was conducted.

${ }^{5}$ As in the article, "He fears mob demonstrators during the World Bank meeting. Will protect his shop with a bat" (my translation) which was published in a Norwegian newspaper before the demonstrations around the World Bank research conference in 2002 (Olsen, 2002-06-13).

${ }^{6}$ Another possible effect of being in an interview situation, that I will not develop further here, is that the person interviewed may feel obligated to live up to the researcher's expectations, to give the "correct" answers.

${ }^{7}$ Which is also why I use the plural form of the word "masculinity" in the title of the article, rather than the singular form. The plural opens up for more complexity and fluctuation not only on a cultural level but also for the individual.
} 